\title{
The Use of High Tunnels to Produce Fruit and Vegetable Crops in North America
}

\author{
Rhonda R. Janke1, May Elfar Altamimi², Mumtaz Khan' ${ }^{1}$ \\ ${ }^{1}$ Department of Crop Sciences, College of Agriculture and Marine Science, Sultan Qaboos University, Muscat, Oman \\ ${ }^{2}$ Department of Horticulture, Forestry, and Recreation Resources 2021 Throckmorton, Kansas State University, Manhattan, \\ USA \\ Email: rhonda@squ.edu.om,mumtaz@squ.edu.om,mtamimi@ksu.edu
}

How to cite this paper: Janke, R.R., Altamimi, M.E. and Khan, M. (2017) The Use of High Tunnels to Produce Fruit and Vegetable Crops in North America. Agricultural Sciences, 8, 692-715. https://doi.org/10.4236/as.2017.87052

Received: June 24, 2017

Accepted: July 25, 2017

Published: July 28, 2017

Copyright $\odot 2017$ by authors and Scientific Research Publishing Inc. This work is licensed under the Creative Commons Attribution International License (CC BY 4.0).

http://creativecommons.org/licenses/by/4.0/ c) (i) Open Access

\begin{abstract}
High tunnels have been used in the United States for more than 50 years, and growers are encouraged to use them more frequently through government cost-share programs. Research on fruits and vegetable production systems has focused on high value crops such as tomato, salad greens, and several fruit crops. Maintaining soil quality and controlling insects and diseases are all issues that growers face. This review looks at current research on these issues as well as economic considerations addressed in the scientific literature. Global statistics and reports are also reviewed that complement the North American studies. Gaps in our understanding are identified, and directions for future research are suggested.
\end{abstract}

\section{Keywords}

Hoop Houses, Plasticulture, Protected Agriculture, Season Extension

\section{Introduction}

The term "high tunnel" often called a hoop house, is currently used to describe structures with a single or double (inflated) layer of polyethylene film stretched over hoops of metal or polyvinyl chloride (PVC). High tunnels (HTs), in contrast to greenhouses, regardless of materials used, are not artificially heated or cooled, but rely on passive ventilation, which saves on both construction and maintenance costs. HTs have been used for many years worldwide, but in the United States the use of HTs has a much shorter history. HTs are gaining in popularity to prolong the production season, increase yields and improve the quality of fruits, high value specialty vegetables and cut flowers. Most commonly, HTs are single-bay structures with roll-up sides, but use of multi-bay complexes 
is becoming more popular for larger scale growers. The number of farm operations growing food crops under protection in the United States (US) has increased three-fold since 1979, and sales have gone up 30-fold in the same time period [1]. Tomatoes, peppers, cucumbers, melons, lettuces, summer squash and eggplants are the primary vegetable crops grown in HTs [2] with small fruit (berries) and tree fruit gaining importance. The use of HTs for the production of horticulture crops includes benefits such as protection from severe weather, faster warming of the soil in the spring, and accurate application of water with the result of reduced disease incidence. HT use is likely to continue to increase as the demand for locally produced fresh horticulture crops continue to expand.

\subsection{Definitions}

High tunnels are not the same as greenhouses, although the greenhouse principle is the basis for the function of high tunnels (Figure 1) [2]. They are stand-alone units placed on good soil and at locations where they can be vented easily through roll-up side walls, large doors, or removable end walls. High tunnels are constructed by stretching a layer of plastic over hoops of metal, and they have no electrical services, automated ventilation, or heating systems [3]. Although there are no permanent heating systems, some growers provide additional heating through the use of a non-vented propane heater during early spring and late fall to protect crops against low temperatures. Drip irrigation or hand watering is primarily used for watering and fertigation [4], though a few growers have also installed over-head sprinklers. They are used to produce a wide variety of crops directly in the soil [5], as contrasted to greenhouses where crops are grown in containers or various types of hydroponic systems. High

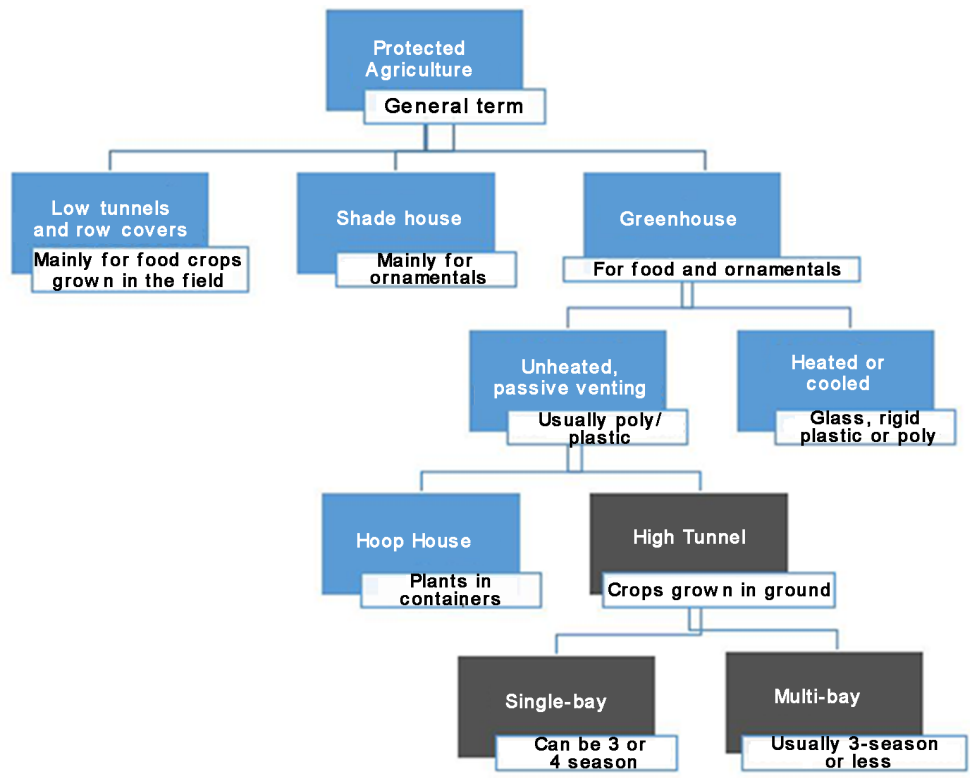

Figure 1. Diagrammatic explanation of terms. The focus of this literature review is on high tunnels, and the fruit and vegetable crops that are grown within them. 
tunnels offer growers a cost effective way to extend the growing season and improve the yield and quality for high-value crops such as fruits, vegetables, and cut flowers [6]. In temperate parts of the world, high tunnels extend the growing season by creating a warmer environment for crop growth [7]. In tropical regions, HTs extend the growing season by protecting crops during the rainy season [8] or providing shade and/or cooling during the hot season [9].

There is sometimes confusion about the use of the term "high tunnel", as compared to other, similar structures. High tunnels are generally similar in structure to what have in the past been called "hoop houses", except that in HTs crops are grown directly in the soil, while in a hoop house flats or containerized plants may be grown on benches or placed on the ground. Neither is heated or top vented. High tunnels are also distinguished from "low tunnels" by size; in HTs, a person can walk into the high tunnel, usually 2 to $3 \mathrm{~m}$ in height, and small equipment, and sometimes even tractors are driven inside for tillage operations. For a low tunnel, wire hoops or other supports are placed over a row of plants in the field for a period of weeks or months, covered with plastic or spun polyethylene, and total size is generally about 1 to $2 \mathrm{~m}$ in width and height. With a low tunnel, the materials must be removed or sides lifted for insects to enter for pollination and for harvest. In both systems, drip irrigation can be used.

High tunnels are different from greenhouses in several important ways. Greenhouses are often heated, cooled, or both using electricity and other fuel sources, and are usually top vented, often with automatic systems set to achieve a certain temperature range within the greenhouse. High tunnels are neither heated nor cooled artificially, and are usually vented by taking off the end walls during summer months or by rolling up or rolling down plastic sheets used as side vents. Thus, the temperature range inside a HT is under much less control. For purposes of farm taxation, HTs are not counted as permanent structures, and not subject to property tax in the way a greenhouse, barn, or other farm improvement might be. Greenhouses may be made from a variety of materials including glass, rigid plastic, polyester/flexible plastic, or any combination. High tunnels are generally made from flexible plastic, with occasional use of rigid plastic for end walls. "Protected agriculture" is a general term that refers to all types of greenhouses, shade houses, HTs, low tunnels, and even floating row cover systems. "Plasticulture" is an even more general term, referring to the use of plastics for structures, mulching, and even irrigation tubing.

High tunnels have two main designs; single bay and multi-bay. With single bay there are two designs (arched/Quonset or gothic/gabled). Gothic HTs have a peaked roof design to suit locations with heavy snow fall. The single bay high tunnels normally range from $1.2 \mathrm{~m}$ to $9.1 \mathrm{~m}$ wide and from $6.1 \mathrm{~m}$ up to $91.4 \mathrm{~m}$ in length [10]. Multiple bay HT structures are more suitable for tree fruit and small fruit crops. However, these tunnels are sensitive to high wind because of the large film surface on the roof [11]. They also are not built to withstand snow loads, and so the plastic film must be removed in winter months and re-installed in the spring or early summer, and are sometimes referred to as "3-season" high 
tunnels. The connections between bays can include a gutter to catch rainwater, but many models simply allow runoff to fall between the beds, which are often grassed, graveled, or covered with landscape fabric to prevent soil erosion between the bays.

\subsection{Historical and Global Use}

Despite having been used in the United States for half a century, HTs have not been adopted as quickly by fruit, vegetable, and flower growers in the US as in many other countries [12]. Emery Emmert is credited with building the first plastic covered greenhouse in the United States in Lexington, KY in 1953, and it remained in use until 1959 [13]. His motives were simply cost savings over the use of glass [14]. In the early 1990's, Drs. Otho Wells and Brent Loy at the University of New Hampshire constructed the first eight HTs used for research in the US at their experimental farm [15].

Early high tunnels/plastic covered structures required annual replacement of plastic, in contrast to current practices where plastic is more durable and UV resistant, requiring replacement only every 3 to 5 years. World-wide, HTs, or plastic structures were being used for horticultural crops in Europe by 1945, and in the 1950's and 1960's in Scandinavia, Russia, southern Europe and the Mediterranean region, Greece, Israel, and also China and Japan [12] [16]. Problems in early models, in addition to non-UV resistant plastic, included the difficulty of heating and cooling the structures, and managing ventilation to reduce condensation. The current use of HTs for season extension rather than as a heated structure along with modifications in ventilation has solved many of these problems.

While overwintering structures have been widely used in the nursery industry, it was not until the early 1990s that research and extension professionals in the Northeast of the United States began to report the potential of these structures for vegetables production [17], initially reporting their great advantage for early production of warm season crops such as tomato (Solanum lycopersicum). Multiple efforts, many by innovative growers [18] [19], have contributed to today's increasing awareness of the potential value of HTs for early or extended season production of fruits, vegetables, and flowers of outstanding quality. Numerous extension efforts in many states in the US have also made a contribution to grower understanding and adoption of HTs and provide valuable on-going information and practical updates [20] [21].

As a percent of current global greenhouse or protected agriculture production, the United States contains only a small fraction of total area. The leader is China, with current estimated production in greenhouses at 2.6 million ha, or about $90 \%$ of estimated global area [22]. China's greenhouse production area in 1999 was estimated at 1.4 million ha [7], up from 9180 ha in 1981, with 460,000 ha of the total greenhouse area in HTs. Other major greenhouse horticultural producers include Korea, Spain, Japan, Turkey, and Italy [23]. Current area in the United 
States is estimated at only $0.3 \%$ of global area [22], which is less than an earlier estimate of about $1 \%$ [2].

Cultivation under plastic film materials is growing in Europe. Data from 21 European countries from 2006 shows a total of 111,550 ha under plastic film (greenhouses and HTs), with an additional 68,991 ha using low tunnels [24]. Greatest areas under protected cultivation were in Spain and Italy, with 53,235 and 25,000 ha in greenhouse and/or HT structures, respectively. By comparison, the United States land in greenhouses and HTs for all crops was 8314 ha in 2014, and only 785 ha for food crops [1]. For Middle East and Arabian Gulf countries, data for land under plastic films is not readily available, but research on protected agriculture in Bahrain was being undertaken as early as 1983 [25], and un-heated plastic covered HTs are widely used in the Jordan River Valley for vegetable crop production [26].

\subsection{Current Status}

Since 2009, USDA conservation programs have been providing funding costshare for HT construction, resulting in over $\$ 61$ million for more than 13,000 HTs by the end of 2014 [27]. Even before this influx of funding, the area of all crops in greenhouses rose from 7016 ha to 8314 ha between 1998 and 2014 [1]. The percentage of protected agriculture area in food crops rose from $4.01 \%$ to 9.44\% during this same time period. Plastic covered greenhouses, as a share of total greenhouse area (which could serve as a rough estimate of area in HTs), was about $50 \%$ of the total area for both survey years. Neither the US Census of Agriculture nor the US Horticulture Census distinguishes between high tunnels and other forms of protected agriculture. Leading states are California, followed by Pennsylvania, New York, and Florida. Tomatoes dominate as the largest area of crop (56\% of area), followed by cucumbers and fresh herbs (8.4\% and $8.3 \%$ respectively). Other major crops grown in protected agriculture are lettuce, peppers, and strawberries [1].

A recent survey of extension horticulturalists in the US [28] found that research was occurring on many horticultural food crops including tomato, several types of fruit crops, other vegetable crops, and specialized growing methods such as organic production, grafting, hydroponic methods, biological pest management, as well as crop rotation sequencing and season extension. A CABI (Commonwealth Agricultural Bureau International) data-base search of refereed journal articles in English from 1980-2015 found 158 papers with "hightunnel" or "high tunnel" mentioned in the title. Of these, 35 were specifically about strawberry production, 26 on tomato, 13 on raspberry, 8 on other fruit crops, 9 on lettuce or leafy greens, 11 on peppers, 6 on melons or cucumbers, and only one or two each focused on seed production, flowers, onions, broccoli, asparagus and fennel. Topics mentioned in the titles from this search included economics (12), disease (12), food quality (11), structures/construction (11) and organic production methods (9). High tunnel production of food crops is beginning to be an active area of research, and of growing interest to producers too. With total crop sales in the United States of over $\$ 796$ million in 2014, the commercial 
value of protected agriculture food crops is significant [1].

\section{Site Selection, Micro-Climate, Coverings and Soil Quality}

\subsection{Site Selection and Construction}

The site planning for HTs requires consideration of most of the same factors used to place and orient other protected environment structures such as greenhouses, cold frames, over-wintering structures and shade and lathe houses. Better site planning is essential for these non-permanent structures because the use of lower cost materials and construction methods can make the structures more vulnerable to stresses [29]. High tunnels can require daily maintenance so the location has to be readily accessible during all production seasons, but at the same time far enough from roads so that damage from farm machinery and other vehicles is avoided. Tunnels are typically sited in a production field, so a HT's impact on the growth and management of the crop around the HT must be considered.

Orientation of HTs affects the amount of sunlight received. For locations north of $40^{\circ}$ latitude, the ridge should be run east to west while, for locations south of $40^{\circ}$ latitude, the ridge should be run north to south taking into consideration avoiding the shadow cast by the structure [30]. Shade is an important factor as it can reduce the effectiveness of the HT. High tunnels should be built at a distance at least twice the height of an object away from it. In addition, the HTs should not be placed in an area that would receive substantial water drainage from other plots or buildings.

High tunnels should be built on a well-drained soil and with drainage aisles or swales between structures. The site should also be level to ensure even irrigation and to facilitate tillage. Most HTs in the United States are built over the soil that will be used to grow the crops [31] though in locations with poor soil, top soil and/or compost can be brought in or added. Wind breaks can be an important protection strategy for HTs where prevailing winds are problematic; they can reduce the damage of strong winds depending on the height, density, orientation and length of the shelter belt [32].

High tunnels are usually securely fastened to the ground through the use of metal posts sunk at least $0.75 \mathrm{~m}$ into the soil, or through the use of a re-bar to hold down the railings on "moveable" high tunnels. Some support posts are equipped with a screw-type structure at their base to allow them to be screwed into the soil to the proper depth for anchoring.

\subsection{Microclimate}

High tunnels change the micro-climate by increasing the number of growing degree days, as well as offering some cold weather protection at night. A study in Saskatchewan found 1891 accumulated growing degree days from May through until the first frost (base $10^{\circ} \mathrm{C}$ ) inside a HT (3-year average) as compared to 1525 for a clear plastic low tunnel, and 1167 in the open field [33]. The HTs only pro- 
vided about $2^{\circ} \mathrm{C}$ protection from spring and fall frost however.

Diurnal temperature flux tends to be greater inside a HT as compared to outside [34]. A double layer plastic cover increased the air temperature an average of $12^{\circ} \mathrm{C}$ in summer and $7.8^{\circ} \mathrm{C}$ in winter, and the addition of poly row covers inside the HT moderated the temperature fluctuation even more, and gave an additional $3.1^{\circ} \mathrm{C}$ of frost protection to the $4.3^{\circ} \mathrm{C}$ frost protection from the HT. Soil temperatures inside the $\mathrm{HT}$ in this study rarely fell below freezing in Kentucky.

A study in Kansas found that the microclimate inside HTs used for strawberry production protected the crowns from winter damage [35]. From December through February the average minimum and maximum crown temperatures were 5 and $12^{\circ} \mathrm{C}$ warmer than those in the field. In central New York state air temperatures experienced large fluctuation inside the HT. It was nearly the same as the outside temperature at night, but rose above freezing during the day inside the tunnel, even when it was lower outside [36]. Soil temperatures fluctuated less than air temperature, with HT soil temperatures remaining significantly higher than those outdoors. The spatial variation within the HT was less than expected, with air temperatures on the edge of a $10 \mathrm{~m}$ wide tunnel being only $2^{\circ} \mathrm{C}$ less than at the center. Similar results were found in India, where minimum and maximum temperatures in December were found to be $2^{\circ} \mathrm{C}$ to $9^{\circ} \mathrm{C}$ higher in a polyhouse than in the open field [37]. Maximum available light intensity inside the polyhouse was about $30 \%$ to $40 \%$ lower than in the open field irrespective of growth stages. Tomato fruit yield obtained from the polyhouse was twice that of the open field, despite the lower light levels.

\subsection{High Tunnel Cover Materials}

Though the plastic covers protect plants from cold temperatures in winter months, they also intercept light, are vulnerable to wind damage, and affect both the quantity and quality of crops grown in HT. This is beginning to be an active area of research, and deserves its own literature review, but a few examples will be described.

Surveys conducted of commercially available products found both UVblocking and UV-transmitting plastics with characteristics of transmitting high levels of photosynthetically active radiation [38]. The resilience of polyethylene film continues to be of interest, especially in harsh environments. A commonly used monolayer polyethylene film used in plasticulture was compared to a new generation 3-layer sandwich structure of one EVA 19 (ethylene vinyl acetate) layer inserted between two low density polyethylene layers [39]. Optical, thermal and mechanical properties were analyzed and found the performance of the multi-layer material was better than the mono-layer, especially resistance to the abrasion effect of sand and wind, subjected to tests in lab experiments. Initial light transmission was greater in the mono layer, but after sand and wind abrasion, the inverse was observed, with less light transmission from the mono layer than the 3-layer system.

In warmer climates where season extension is not an issue, polypropylene fa- 
bric is used to protect plants from insects and sunlight. In a study in Spain, light transmission under the fabric varied from $65 \%$ to $85 \%$ depending on the accumulation of dust and/or water vapor [40]. Air temperature under the cover as compared to the field was higher at the beginning at the cropping season but similar later. Above-ground biomass of crops including Chinese cabbage, beet root, lettuce and spinach was not increased due to improved micro-climate under the fabric, though the salad greens had a larger leaf area index, the beet root yield was higher, and overall crop quality was enhanced.

More research needs to be done on the possible effect of HTs on the phytochemical composition of food crops, such as antioxidant and phenolic content. The ultra-violet (UV) blocking characteristics of the standard plastic used for HTs was found to lower the total phenolic acid contents of tomato fruits by $20 \%$ as compared to UV-transparent plastic [41]. Similarly, high tunnels reduced the phenolic content of several leafy vegetables tested [42]. In a study which compared three plastic films, only the red lettuce cultivar "Lollo Rosso", showed increased phenolics under high UV transmitting plastic [43] while green lettuce, strawberry, raspberry and blueberry showed no difference. More research is needed to determine the mechanism for this response to UV light and phenolic content. In addition, more research is needed on the effect of various light wavelength spectra on plant growth, insect, and disease control.

\subsection{Soil Quality and Management}

Maintaining soil quality and fertility in a sustainable manner can be challenging in intensively cropped systems such as those used in HTs [44]. It is recommended that soil preparation, including tillage, mulching, composting and cover crop management, begins one year before construction [45]. Soil organic matter (SOM) management has a major effect on soil health and increased SOM has been shown to improve physical, chemical, and biological soil quality indicators such as water absorption and retention, soil biological activity, cation exchange capacity, nutrient availability, microbial biomass, carbon and nitrogen pools, and disease suppression [46].

In a survey of 81 growers and $185 \mathrm{HTs}$ in four Midwest states [31] 14\% of growers surveyed considered soil quality to be a problem. There were significant correlations between the grower's perception of soil quality problems and observations of clod formation, surface crusting, surface mineral deposition and hardpan presence. However, higher levels of electrical conductivity (EC) were only found in a small portion of HTs as compared to adjacent field sites. This result was not correlated with years of use, and levels were not high enough to limit crop growth. Organic amendments were used by $35 \%$ of growers, and organic and non-organic combinations were used by $50 \%$ of growers [31].

Repeated applications of organic amendments can result in increased microbial activity and active soil carbon [47]. Organic fertility treatments under HT conditions included hairy vetch as a green manure crop, dehydrated alfalfa meal, and partially composted and pelletized chicken manure. Peppers yielded the 
same across all fertility treatments, but Swiss chard yield was lower with the green manure as a nitrogen source as compared to urea. The EC levels were higher in HTs as compared to open field, but not limiting [47]. In a similar study, soil quality was evaluated after eight years in a comparison of HTs with open field conditions under conventional and organic (compost) management [48]. Conventional fertilizers resulted in increased soil $\mathrm{pH}$ and salinity while under organic soil management the soil carbon pools were higher in both field and HT, with the largest increase, especially in the particulate organic matter fraction, in the HT systems. Yields from these experiments found no significant differences in most seasons between organic and conventional, but yields of both tomato and pak choi were two to three times higher in the HTs as compared to field plots [49].

High tunnels managed with three years of composted manure resulted in significantly better soil quality, as measured by total carbon, total nitrogen and microbial activity. Soil phosphorus and potassium levels were also significantly higher [50]. In contrast, HTs managed with "high input intensive cultivation" for 20 years increased soil salinity and also resulted in a decline in organic carbon [51]. The soils under high input management also had lower total microbial biomass and microbial diversity as compared to less intensively cropped soils.

One interesting difference between HT and field soil fertility management is that nitrogen may accumulate in HT systems due to mineralization from organic matter sources, but there is no leaching due to rain-fall. Therefore, watering systems, rates, and the temperature regime inside the HT influence the rate of nitrogen release from organic sources, and the possibility of loss due to volatilization or leaching. Typically, more $\mathrm{N}$ will be mineralized in warmer soils with optimal moisture and aeration than in cool, wet or arid soils. Microbial activity is restricted when soils contain too much or too little moisture, or are at sub-optimal temperatures [50]. Very little microbial activity occurs when the soil temperature drops below $4^{\circ} \mathrm{C}$. In HTs the minimum soil temperature may be 1 to $7^{\circ} \mathrm{C}$ warmer than outside the tunnel [52] [53] enhancing the environment for microbial activity.

In HT-grown tomatoes in Maine, when commercially-available composts were applied at a rate of $300 \mathrm{~kg}$ total N/ha, the compost-amended soils mineralized $4 \%$ to $6 \%$ of the compost organic $\mathrm{N}$ the first year after compost application. Marketable yield of tomatoes was correlated with compost total inorganic $\mathrm{N}$ irrespective of source [54]. Research comparing conventional and organic sources of nitrogen in field vs. high tunnel found that they were similarly available to both tomato and pak choi and were not limiting [49].

In summary, soil quality is not just a function of whether the cropping system is managed within a HT or in an open field, but more to do with whether organic matter additions take place within the context of soil fertility management. Organic amendments can preserve and enhance soil fertility in agriculture in HT intensive farming systems. Future research should identify organic amendments that optimize soil fertility and soil quality. 


\section{Cropping Systems}

\subsection{Vegetable Crops}

High tunnels are a management tool that enables producers to realize greater returns per unit of land. Many benefits accrue to growers: earlier crop production and higher yields, more efficient use of water and fertilizers, reduced soil erosion, and better management of insects and diseases [55]. Vegetable crops that have shown significant increases in earliness, yield, and fruit quality with the use of HTs include tomato, pepper, cucumber, squash, eggplant, watermelon and okra [55].

\subsubsection{Tomatoes}

Many researchers have evaluated the influence of HTs on tomato production. In North Carolina, heirloom tomato yields in HTs and field systems were similar the first year, but 33\% greater in the HT system than the field the second year [56]. Disease incidence (tomato spotted wilt virus Tospovirus and Gray Leaf Spot Stemphylium spp.) was lower in the HT compared to the field in both years.

Reduced leaf wetness under high tunnel conditions is a major factor in reducing tomato leaf fungal disease in HT as compared to open field as a result of using drip irrigation systems and eliminating rainfall [49]. In Western Washington, the severity of late blight (Phytopthora infestans) was significantly lower in HT plots as compared to open-field plots, even with rescue foliar fungicide applications [57]. The HT tomatoes experienced a higher incidence of physiological leaf roll as compared to open-field, but total tomato yield was still higher in the HTs. [57].

A tomato variety trial in New Hampshire found that leaf mold (Fuvlivia fulva) and powdery mildew (Oidium lycopersici) were present in the HT, but only in years two and three for the leaf mold, and year two for powdery mildew [58]. Yields went down each year over the course of the three-year trial in continuous (no rotation) tomatoes [58]. Some varieties yielded consistently well and were resistant to disease, while others were susceptible, and some were showed varied responses depending on conditions.

One common practice in HTs is to extend the season by moving up the planting date. In Mississippi, earlier plantings provided earlier harvests without yield loss [59]. However, there was no planting date effect on the total marketable yield for tomatoes, eggplants or banana peppers. Similarly, in a trial with heirloom and hybrid tomatoes, there was no increase in total yields in HTs compared to open field, but there were higher marketable yields and lower early blight incidence [60].

In an organic transition experiment in HTs, marketable yield of organically grown tomatoes was lower in year 1 but the differences between organic and conventional tomatoes were insignificant in years 2 and 3 [50]. A three-year study comparing organic vs. conventional management of tomatoes in high tunnels vs. open field in Kansas found that yields were significantly higher in the 
HT systems, but not significantly different between organic and conventional [49].

Energy use and yield were compared for a trellised field tomato crop, a HT crop, and a modern greenhouse tomato crop in upstate NY. High tunnel productivity was found to be double that of field productivity. Of the three production systems, the HT used the least energy per kg of product produced [61]. The shortness of tomato production season, which is controlled by climate, is a major limitation to the expansion of this production system in New York State.

\subsubsection{Cool Season Crops and Salad Greens}

In contrast to tomatoes, which are only grown during the non-winter months in temperate climate regions under HTs, cool season crops like brassicas and salad greens can be grown nearly year-round in a variety of situations. In New Hampshire, fall planted broccoli could be overwintered in unheated HTs for spring harvest under Zone 5 hardiness conditions [62]. The use of a secondary low tunnel inside the HT covered with heavy row cover significantly increased winter survival, earliness, yields and shoots quality.

Asian greens, lettuce and spinach were evaluated under HT conditions in Idaho and Washington, in cold temperate and mild marine climates, respectively [63]. Location and cultivar choice both impacted yield; Asian greens grew faster compared with spinach and lettuce and planting dates also influenced yield. Overall, the research suggested that it was possible to grow cold-tolerant cultivars of these crops in northern climates.

High tunnels are also being used to extend the growing season into hotter months for cool season crops. Eight leaf lettuce cultivars were grown in HTs covered with shade cloth and in open fields in northeast Kansas [64]. Lettuces grown in HTs covered by shade cloth had a lower bolting rate, but decreased yield relative to that in the open field. Hence, summer lettuce production could not be recommended in HTs or in open fields in northern Kansas. In another study, three different climates were compared; hot and humid, hot and dry, and cool and humid for HT and open field organic production of lettuce [65]. High tunnel production systems offered greater control of environments suitable for lettuce, especially in climates that are hot and humid and hot and dry, where temperature variations may affect lettuce quality. Spring and fall planted pak choi in HT in Kansas yielded three times as much as field planted plots in both organic and conventional systems, even though temperatures are milder during these seasons and should be optimal for the growth of pak choy [49].

\subsection{Fruit Crops}

A number of fruit crops have been evaluated under HT conditions ranging from strawberries to brambles and even tree fruits. Yields, fruit quality and time of harvest under HTs have been compared to those under field conditions in a range of climates, including Georgia and California, and northern Michigan and Canada (subtropical and Mediterranean to northern temperate conditions). 


\subsubsection{Strawberries}

Strawberry production in high tunnels has been evaluated in Utah [66], West Virginia [67], Kansas [35] and Quebec [68]. In most of these studies, strawberries were transplanted as plugs into the HTs in the fall, and then overwintered for spring harvest. In all of the studies reported, both June bearing and day neutral strawberries came into production in HT about a month earlier than those in open fields. In West Virginia [67] the variety "Chandler" had 90\% marketable fruit from a HT, while only $60 \%$ was marketable from open field plots. The Utah experiment [66] also found that both June bearing and day neutral types yielded better under HT conditions.

In Kansas [35], HT strawberries were about 5 weeks earlier to harvest, and also had larger fruit with higher soluble solids concentration as compared to field grown berries. Four colors of plastic mulch were compared in HTs in Canada, and found that HTs extended the fruiting season by about a month, and that fruit quality as measured by Brix (soluble solids as an estimate of sugar) was also higher under HTs. Mulch color affected fruit size but not overall quantity or quality, with the exception of the black mulch which caused excessive heat inside the HT [68]. The use of supplementary pollination in HTs has been show to result in better economic returns for strawberries by increasing yield and decreasing the incidence of misshapen fruit [69].

\subsubsection{Raspberries}

Raspberries have been grown in HTs in California since the early 1990's [70] where growers plant primocane fruiting raspberries on $2.5 \mathrm{~m}$ wide rows with drip irrigation, harvest them approximately 5 months later, and then prune back the canes and harvest again in another three to four months.

Other, more northern climates have also found advantages of HT production of raspberries. Organic raspberries grown in HTs in Quebec, Canada, have a cropping season that is extended by about 40 days [71]. The HTs resulted in higher yields, larger fruit size, and higher plant and soil nutrient content than fertilized non-organic control plots. In upstate NY researchers were also able to obtain a late harvest of "Heritage" raspberry by using several techniques such as late pinching, applying heavy straw cover or mowing canes [72]. A higher price was obtained with the late harvest as compared to a main season harvest.

However, in Pennsylvania, only $18 \%$ to $50 \%$ of the potential fall crop from "Heritage" and "Autumn Britten" varieties was harvested due to early first frosts, even inside a HT [73]. Subsequent trials were able to overcome some of this by planting earlier and thinning canes in order to get fall crops of raspberries to bear about a month earlier. They also noted that no fungicides were required for disease control due to the dry conditions in the high tunnels.

In southwestern Michigan, researchers also noted the absence of cane and leaf disease due to the lack of free moisture in the HT, which would be needed for infection by fungal pathogens [74]. The incidence of gray mold (Botrytis cinerea) was $1 \%$ in the HT and $13 \%$ in the field. Several other diseases; including leaf spot 
(Sphaerulina rubi), cane anthracnose (Elisinoe veneta), spur blight (Didymella applanata) and botrytis cane blight (B. cinerea) were common in the field but absent in the HT. The yields of both primocane and floricane fruiting cultivars of red raspberry in mulit-bay HTs were twice as high per unit area in the HT as compared to open field for the most productive cultivars. Date of first harvest and berry quality were similar in the field and HT, but the tunnel environment tended to increase plant vigor, yield and lengthened the harvest period. Phytonutrient content was tested in three of the varieties, but with inconsistent results and a significant genotype by environment interaction [74].

In Arkansas trials, all primocane fruiting raspberry cultivars tested had higher weekly yield, cumulative yield, and larger fruit size in HTs. There was also an additional 3 to 5 weeks of harvest, and reduced fruit loss due to rots, which resulted in increased marketable yield [75].

A study of aphid populations on raspberries in the UK found that the plants grew faster and had 35\% less foliar amino acids as compared to those in the field but aphid populations were similar in both environments. Growing temperatures inside the tunnels were $7^{\circ} \mathrm{C}$ to $10^{\circ} \mathrm{C}$ higher than in the open field and should have resulted in an outbreak of aphids, but faster aphid development inside the HT was not realized because of the lower amino acid content of the host plants. They concluded that growing these crops in protected environments will not necessarily cause an increase in aphid populations, but it did alter aphid-plant interactions [76].

\subsubsection{Blackberries}

Blackberries have been successfully grown in multi-bay HTs in western Oregon [77]. Primocane fruiting blackberries under HTs were compared to those in the open field, though the plastic was not put on the HT until just prior to harvest. This growing system resulted in a harvest period that lasted 3 weeks longer into the fall, and had higher cumulative yields. Harvest began the same week (midSeptember) and the use of HTs did not affect primocane growth. The authors suggest that an economic analysis is necessary because of the extra time required to put on, vent, and then remove the plastic each year, in addition to the cost of the structure.

When multi-bay HTs were used for primocane blackberry production in Michigan, different results were obtained from those observed in Oregon [78]. In this case, the plastic was put onto the HT in May and removed in early November. Yields were low the second year after establishment, and in years 3 and 4 there was low fruit set in the HT. The fruit matured from early August to mid-October with no period of concentrated ripening. Up to $60 \%$ of the canes did not produce fruit by the end of each season. High temperatures were recorded in the HT in July and August $\left(30^{\circ} \mathrm{C}\right)$ as compared to outside $\left(25^{\circ} \mathrm{C}\right)$ which may have contributed to poor pollination and/or fruit set. Crown gall was also a problem in the high tunnels. It was concluded that in Michigan where possible snow load prevents putting the plastic on any earlier, the short growing season 
and cold winters limit production unless tipping and training strategies can be developed to promote late summer or fall production.

In Pennsylvania, trials with the blackberry variety "Triple Crown" resulted in no winter die-back and good yields for 4 years under (year-round) HT conditions [73]. However, a thornless blackberry variety ("Chester") failed to leaf out each spring, which was attributed to cold winter temperatures or temperature fluctuations in the HT.

Blackberry variety trials in Arkansas, that compared HTs to open fields found a significant cultivar by location interaction, which was not consistent from year to year [79]. The HTs were covered year round, and side-walls were closed during the winter months after plants received sufficient cold temperatures to break dormancy. They were opened or vented if temperatures went above $35^{\circ} \mathrm{C}$. In one trial, "Prime Jim" and "Prime Jan" had higher weekly and cumulative yields and heavier average berry weight in HTs, while the variety "APF46" did not. In a second season, "Prime Jim" and "APF46" had higher yields and greater berry size in the HTs than the cultivar "Prime Jan" [75].

\subsubsection{Blueberries}

Southern highbush blueberries were evaluated for their suitability for production in HTs in northern Georgia [80]. In those conditions, HTs did not retain heat at night or provide frost protection without the use of propane heaters. The HT environment accelerated vegetative and reproductive growth compared with the open field by 38 to 39 days. In 2007 low yields were obtained in the HT, probably due to poor synchronization of flowering between the two cultivars evaluated (required for cross pollination). Under field conditions the flowering time of the two varieties was synchronized. In 2008 and 2009 the crops were lost to frost damage. Growers in more northern climates have used multi-bay high tunnels for high bush blueberry production successfully, but there are apparently no research studies for these locations yet.

\subsubsection{Sweet Cherries}

Sweet cherries are the largest fruiting plant attempted in HTs in the US. In Pennsylvania [18], a 0.24 ha multi-bay HT was installed over seven-year old sweet cherry trees grown on dwarf rootstock in 2003, and in 2004 a 0.36 ha multi-bay HT was installed over five-year old trees. Bird netting around the perimeter of each HT was used to exclude birds, so bumblebees were introduced for pollination. The tunnels were vented on hot days and trees were pruned back to $3.6 \mathrm{~m}$ inside the tunnels. More recent plantings of cherries in HTs have been at twice the density of open field trees. Bacterial canker was reduced in HTs, as well as less frost damage, resulting in a higher percent marketable fruit and better shelf life of the cherries. Bird damage in field grown cherries is typically around $20 \%$.

In Michigan cherries have been planted into multi-bay HT systems, including some where the tunnels are installed over an existing orchard [81] [82]. HT growing conditions include $10 \%$ more growing degree days inside the tunnel as 
compared to outside, $26 \%$ lower daily light integral, the trees were $24 \%$ taller, had a higher leaf area, but no difference in the number of lateral shoots. Fruit weight per cherry was higher in the HTs, leading to higher prices, but total yields were similar inside and outside of the HTs [81].

Results in Michigan also showed reduced levels of Japanese beetle (Popillia japonica), cherry leaf spot (Blumeriella jaapii), bacterial canker (Pseudomonas sytringae), plum curculio (Conotrachelus nenuphar) and cherry fruit fly (Rhagoletis cingulate) in the HTs [81] [82]. Though the tunnels were open, these pests did not move into the HT trees as fast as in the open field grown trees. Two-spotted spider mites (Tetranychus urticae) were more prevalent inside the tunnel while cherry aphids (Myzus cerasi) were a problem both inside and outside. Bird damage was minimal due to the inclusion of bird netting. Powdery mildew (Podosphaera clandestine) was more prevalent inside the HT for the first three years, but there were no infections in later years. Brown rot (Monilinia fructicola) was present both inside and outside [81]. No synthetic insecticides or fungicides were used in the Michigan trials in order to evaluate pest pressure.

In a year with a lot of rain, $91 \%$ of the variety "Lapins" and $89 \%$ of "Rainier" cherries had cracking damage outside, while inside the HT the damage was only $32 \%$ and $60 \%$, respectively [82]. Gutters or other ways of keeping rain from getting into the HT might have reduced the cracking incidence inside the HT even more. Cherry growers in England report that marketable yields increase by 25 to $30 \%$ due to reduced cracking [83]. Gross return estimates show that the cost of the high tunnel construction could be covered by the second year of production, especially if sales are to a local or specialty market [82].

\section{Economic Comparisons}

Although HTs have proven to be economically advantageous to farmers who wish to capitalize on high prices from an extended growing season, permanent HT structures do represent a significant capital investment. The cost for a standard size tunnel, including plastic and all the materials required for construction can represent a considerable initial investment. In general, commercially-available single-bay HT kits range from \$US 24.20 to $\$$ US $53.80 / \mathrm{m}^{2}$ depending on tunnel dimensions and features.

A high tunnel guide for New England growers was created using data from Cornell, Michigan State, and Pennsylvania State Universities [84]. Cost estimates for HT construction were $\$$ US $10.66 / \mathrm{m}^{2}$ or $\$$ US 40,500 or a 0.40 ha for a unit of nine multi-bay tunnels $(61 \mathrm{~m} \times 7.3 \mathrm{~m}$ per bay) for labor and materials. The estimate for a single bay HT $(9.1 \mathrm{~m} \times 29.3 \mathrm{~m})$ was $\$$ US 9632 for labor and materials, or $\$$ US $35.95 / \mathrm{m}^{2}$. In both of these scenarios, the crops grown in the HT paid for the initial capital costs in either two or three years.

In western Washington a study found that it was $43 \%$ more profitable to grow lettuce in the open field, but three times more profitable to grow tomatoes in HTs. They found it was five times more expensive to grow lettuce and eight times more expensive to grow tomatoes in HTs as compared to the open field 
largely because of differences in labor costs [85]. However, HT-grown lettuce and tomato had three and four times greater marketable yields, respectively.

Research station data from North Carolina were used to conduct an economic analysis based on a two year study of HT and open field production systems of heirloom tomatoes. Both systems were profitable but profits were higher in the open field in 2007 and in the HT in 2008. When sensitivity analysis was performed, both systems are profitable at moderate prices or higher. At $\$ 2.60$ per lb, a local seasonal average price, the payback period for HTs ranged from two to five years [86].

A Rhode Island study compared both low and HTs to open field production for muskmelon in a peri-urban market farm [87]. Both tunnel growing systems increased the rate of growing degree-day accumulation, and increased the earliness of harvest. The HT was more productive in yield per hectare, but this was due to a higher planting density, not higher yield per plant. Marketable yields from the low tunnels were also higher than open field, and melons had a higher concentration of soluble solids (a measure of sweetness). The increased HT yields were not enough to offset the increased cost of production for a single growing season. The capital cost of low tunnels was recovered if yield was higher than the open field by only $15 \%$, which was achieved in the study.

A multi-year investigation was conducted using nine case studies in Michigan [88]. Their results found a range of values in terms of construction time, labor, and revenue, but found an average time for recovering the initial capital and related construction costs was 4.2 years before the HTs were profitable. For vegetables grown in HTs in Saskatchewan, 1.6 growing seasons would be required to make back the capital cost of HTs when growing peppers, 2.6 seasons for melon, and 4.3 seasons for tomatoes [33].

A simulation of 500 different economic scenarios for blackberries grown in HT systems in Arkansas found that even though the potential gross returns from the HT are high, the present value distributions of gross returns did not offset the initial cost of the HT in half of the simulations [89]. Overall, they found that open-field production had a higher likelihood of exceeding the break-even cost over the life of the enterprise. The break-even probability was sensitive to the percentage of yield sold and the percentage of retail price received by the producer.

\section{Future Directions}

Though the literature has many examples of research on fruits and vegetables grown in high tunnels, there remain gaps or areas where new studies could make a contribution.

1) Most studies were two or three year trials with annual or perennial crops. Some included economic analyses along with data on yields and/or soil properties. None that we examined discussed crop rotations that would be suitable for a HT. For organic growers in particular, a three-year crop rotation is required for certification. In some studies the HTs were only profitable if a high value crop 
was grown. Which high value crops or sequence of crops might be used to achieve a 3-year rotation?

2) Most economic comparisons contrasted a HT with open field production, and one compared HTs to low tunnels. Other sorts of protected agriculture systems could be contrasted to HTs; for example heated/cooled greenhouses, hydroponic systems, and others.

3) Within a North American context, most studies were conducted in a mild temperate or short season northern temperature climatic regime. Do high tunnels offer advantages when used in subtropical or warmer climates? World-wide, HTs are used in Spain, Jordan, and other arid and tropical locations [16]. Would they also work in similar climates in the U.S? Limited data from Texas [65] and simulation analysis from New Mexico [6] suggest that these are challenging climates and more work is needed for HT production systems to be successful and profitable. In the high plains of Texas for example, HTs only resulted in a slight yield advantage with lettuce in the two years of the trial, but could reduce damage from wind and blowing dust and achieve earlier marketable yield.

4) Similarly, thermal screens and shade cloth offer opportunities for HT management in warmer climates such as in Pakistan [9]. There seemed to be litthe research on these materials and technologies in North America.

5) In many cases, studies of pest incidence in HTs (disease, insects, and weeds) was lower in HTs as compared to open field, largely due to lower humidity, control of leaf wetness, and less water between rows which reduces weed pressure. In a few cases, pest levels were higher [90]. More studies specifically on biocontrol and organic controls within the HT context would be helpful to organic producers and others wishing to reduce pesticide use.

6) Soil quality can be enhanced, not degraded, if organic amendments are used in HT production systems. Studies to look at which amendments are most useful in HT systems without resulting in excess accumulation of some nutrients or higher EC levels would be worthwhile [91].

7) Overall the production of plastic globally has increased $10 \%$ every year, from 1.3 million tons in 1950 to 225 million tons in 2004. High tunnels are large users of plastic, which must be replaced and disposed of every few years. Future important issues include the ability to recycle the plastic, and make sure it doesn't get disposed of in a way that has detrimental environmental consequences [24].

8) The risk of other types of environmental degradation and human health consequences are present when high tunnels are adopted on a large scale, such as in Almeria, Spain [92]. We didn't find any research that addresses these issues.

9) Though short-term economic analysis was done on several locations, the long term impact of government policies, either in the forms of subsidies, or in allowing the import of competing produce coming in from other countries with lower costs of production will have a long-term impact on the overall profitability and sustainability of HTs. Some programs initially started to subsidize HT construction and promote rural development in countries such as Pakistan [93] 
have now failed due to the low prices received by producers [94]. In the US the expansion of fruit and vegetable production as an industry appears to be limited by competition with cheap produce imported from countries with lower labor costs, since land planted to fruits and vegetables has steadily declined since a peak in the 1920's [1].

10) Floral crops can be profitable crops in HTs [95], but research on their production has been only been explored to a limited extent [96]. Cucumbers and fresh herbs were among the highest produced crops in protected agriculture in the US agriculture census, but no research on their production in HTs was found. Future research in high tunnel environments should consider these and other crops, and offer diversification alternatives to food crop producers.

11) Though the US Census of agriculture collects data on farm production costs, methods, and value, neither the five-year Census of Agriculture nor the periodic Census of Horticultural crops distinguishes between "high tunnels" and "greenhouses." It would also be useful if international data (FAO for example) also created distinct categories for heated/cooled structures and other types of protected agriculture such as HTs in their surveys. The rapid growth in this method of growing, in US and world-wide, merits more attention.

In conclusion, though much has been done, there is more research needed to further our understanding of HTs as one form of protected agriculture for fruit and vegetable production, both in the North American context, and globally.

\section{References}

[1] National Agricultural Statistics Service (2014) US Department of Agriculture. Census of Agriculture; Horticultural Specialties. http://www.agcensus.usda.gov/Publications

[2] Lamont, W. (2009) Overview of the Use of High Tunnels Worldwide. Horttechnology, 19, 25-29.

[3] Lamont, W.J.J., Mcgann, M.R., Orzolek, M.D., Mbugua, N., Dye, B. and Reese, D. (2002) Design and Construction of the Penn State High Tunnel. Horttechnology, 12, 447-453.

[4] Lamont, W.J.J. (2013) High Tunnel Construction and Production in a Large Metropolitan City. Acta Horticulturae, 987, 45-47. https://doi.org/10.17660/ActaHortic.2013.987.5

[5] Lamont, W.J.J., Orzolek, M.D., Holcomb, E.J., Demchak, K., Burkhart, E., White, L. and Dye, B. (2003) Production System for Horticultural Crops Grown in the Penn State High Tunnel. Horttechnology, 13, 358-362.

[6] Hecher, E.A.D.S., Faluk, C.L., Enfield, J., Guldan, S.J. and Uchanski, M.E. (2014) The Economics of Low-Cost High Tunnels for Winter Vegetable Production in the Southwestern United States. Horttechnology, 24, 7-15.

[7] Jiang, W., Qu, D., Mu, D. and Wang, L. (2004) Protected Cultivation of Horticultural Crops in China. Horticultural Reviews, 30, 115-162.

[8] Jensen, M.H. and Malter, A.J. (1995) Protected Agriculture: A Global Review. World Bank Publications, Washington DC.

[9] Balliu, A. and Sallaku, G. (2008) Microclimate Control in Protected Cultivation. In: Abbasi, N.A. and Habib, U., Eds., Protected Horticulture, Department of Horticul- 
ture, University of Rawalpindi, Rawalpindi, 81-96.

[10] Orzolek, M.D. (2013a) Increasing Economic Returns to High Tunnels with Specialty Crops. Acta Horticulturae, 987, 83-88.

https://doi.org/10.17660/ActaHortic.2013.987.11

[11] Kratky, B. (1983) PVC Greenhouses for Non-Windy Conditions in Hawaii. Hawaii Agricultural Experiment Station, Honolulu.

[12] Wittwer, S.H. (1993) World-Wide Use of Plastics in Horticultural Production. Horttechnology, 3, 6-19.

[13] Emmert, E.M. (1955) Low-Cost Plastic Greenhouses. Agricultural Experiment Station Progress Report 28. University of Kentucky, Lexington.

[14] Orzolek, M.D. (2013b) Status of High Tunnels in the US. Acta Horticulturae, 987, 29-32.https://doi.org/10.17660/ActaHortic.2013.987.2

[15] Wells, O.S. (1996) Rowcover and High Tunnel Growing Systems in the United States. Horttechnology, 6, 172-176.

[16] Wittwer, S.H. and Castilla, N. (1995) Protected Cultivation of Horticultural Crops Worldwide. Horttechology, 5, 6-23.

[17] Wells, O.S. and Loy, J.B. (1993) Rowcovers and High Tunnels Enhance Crop Production in the Northeastern United States. Horttechnology, 3, 92-95.

[18] Blomgren, T. and Frisch, T. (2007) High Tunnels: Using Low-Cost Technology to Increase Yields, Improve Quality, and Extend the Season. Cornell University Cooperative Extension, Regional Farm Food Project, New York.

[19] Wiediger, P. and Wiediger, A. (2003) Walking to Spring. Au Naturel Farm, Smith Grove.

[20] Kansas State University Research and Extension \& the University of Nebraska, Lincoln (2013) Hightunnels. http://hightunnels.org/

[21] Everhart, E., Hansen, R., Lewis, R.D., Naeve, L. and Taber, H. (2010) Iowa High Tunnel Fruit and Vegetable Production Manual. Iowa State University, Ames.

[22] Kacira, M. (2011) Greenhouse Production in US Status, Challenges, and Opportunities. Proceedings of GIGR International Symposium 2011 Sustainable Bioproduction- Water, Energy, and Food, Tokyo, 19-23 September 2011.

[23] Tuzel, Y. and Oztekin, G.B. (2015) Protected Cultivation in Turkey. International Society for Horticultural Science, 55, 21-26.

[24] Scarascia-Mugnozza, G., Sica, C. and Russo, G. (2011) Plastic Materials in European Agriculture: Actual Use and Perspectives. Journal of Agricultural Engineering Research, 42, 15-28. https://doi.org/10.4081/jae.2011.28

[25] Food and Agriculture Organization of the United Nations (1983) Research and Demonstration on Protected Vegetable Production-Bahrain: The Study and Improvement of Soil Productivity under Plastic Tunnels and Open Field Conditions. Based on the Work of Amer, S.A., FAO Soil Fertility Specialist. Food and Agriculture Organization of the United Nations, Rome, 169.

[26] National Agriculture Information System, Hashemite Kingdom of Jordan. http://www.nais-jordan.gov.jo/Pages/Index.aspx?CMSId=8

[27] National Sustainable Agriculture Coalition (2016) Environmental Quality Incentives Program: EQIP Seasonal High Tunnel Initiative.

Http://Sustainableagriculture.Net/Publications/Grassrootsguide/Conservation-Envi ronment/Environmental-Quality-Incentives-Program/\#Hightunnels

[28] Carey, E.E., Jett, L., Lamont, W.J., Nennich, T.T., Orzolek, M.D. and Williams, K.A. 
(2009) Horticultural Crop Production in High Tunnels in the United States: A Snapshot. Horttechnology, 23, 37-43.

[29] Spaw, M. and Williams, K.A. (2004) Full Moon Farm Builds High Tunnels: A Case Study in Site Planning for Crop Production Structures. Horttechnology, 14, 449454.

[30] Bachmann, J. (2005) Season Extension Techniques for Market Gardeners. National Sustainable Agriculture Information Service, Washington DC.

[31] Knewtson, S.J.B., Carey, E.E. and Kirkham, M.B. (2010) Management Practices of Growers Using High Tunnels in the Central Great Plains of the United States. Horttechnology, 20, 639-645.

[32] Brandle, J.R., Hodges, L. and Zhou, X.H. (2004) Windbreaks in North American Agricultural Systems. In: Nair, P.K.R., Rao, M.R. and Buck, L.E., Eds., Anonymous New Vistas in Agroforestry, Springer, Berlin, 65-78. https://doi.org/10.1023/b:agfo.0000028990.31801.62

[33] Waterer, D. (2003) Yields and Economics of High Tunnels for Production of Warm-Season Vegetable Crops. Horttechnology, 13, 339-343.

[34] Ward, M.J. and Bomford, M.K. (2013) Row Covers Moderate Diurnal Temperature Flux in High Tunnels. Acta Hort, 987, 59-66. https://doi.org/10.17660/ActaHortic.2013.987.8

[35] Kadir, S., Carey, E. and Ennahli, S. (2006) Influence of High Tunnel and Field Conditions on Strawberry Growth and Development. Hortscience, 41, 329-335.

[36] Wien, H.C. (2009) Microenvironmental Variations within the High Tunnel. Hortscience, 44, 235-238.

[37] Kumri, P., Ojiha, R.K., Abhivyakti, A.W. and Rajesh, R.P. (2014) Microclimatic Alteration through Protective Cultivation and Its Effect on Tomato Yield. Journal of Agrometeorology, 16, 172-177.

[38] Krizek, D.T., Clark, H.D. and Mirecki, R.M. (2005) Spectral Properties of Selected UV-Blocking and UV-Transmitting Covering Materials with Application for Production of High-Value Crops in High Tunnels. Photochemistry and Photobiology, 81, 1047-1051. https://doi.org/10.1562/2005-08-09-RA-645

[39] Adam, A., Kouider, S.A., Youssef, B., Hamou, A. and Saiter, J.M. (2005) Studies of Polyethylene Multi-Layer Films Used as Greenhouse Covers under Saharan Climatic Conditions. Polymer Testing, 24, 834-838. https://doi.org/10.1016/j.polymertesting.2005.07.002

[40] Gimenez, C., Otto, R.F. and Castilla, N. (2002) Productivity of Leaf and Root Vegetable Crops under Direct Cover. Scientia Horticulturae, 94, 1-22. https://doi.org/10.1016/S0304-4238(01)00356-9

[41] Luthria, D.L., Mukhopadhyay, S. and Krizek, D.T. (2006) Content of Total Phenolics and Phenolic Acids in Tomato (Lycopersicon exculentum Mill.) Fruits as Influenced by Cultivar and Solar UV Radiation. Journal of Food Composition and Analysis, 19, 771-777. https://doi.org/10.1016/j.jfca.2006.04.005

[42] Zhao, X., Carey, E.E., Young, J.E., Wang, W.Q. and Iwamoto, T. (2007) Influences of Organic Fertilization, High Tunnel Environment, and Postharvest Storage on Phenolic Compounds in Lettuce. Hortscience, 42, 71-76.

[43] Ordidge, M., Garcia-Macia, P., Battey, N., Gordon, M., Hadley, P., John, P., Lovegrove, J., Vysini, E. and Wagstaff, A. (2010) Phenolic Contents of Lettuce, Strawberry, Raspberry, and Blueberry Crops Cultivated under Plastic Films Varying in Ultraviolet Transparency. Food Chemistry, 119, 1224-1227. 
https://doi.org/10.1016/j.foodchem.2009.08.039

[44] Montri, A. and Biernbaum, J. (2009) Management of the Soil Environment in High Tunnels. Horttechnology, 19, 34-36.

[45] Sarrantonio, M. (1994) Northeast Cover Crop Handbook. Rodale Institute, Kutztown.

[46] Gaskell, M., Fouche, B., Koike, S., Lanini, T., Mitchell, J. and Smith, R. (2000) Organic Vegetable Production in California-Science and Practice. Horttechnology, 10, 699-713.

[47] Rudisill, M.A., Bordelon, B.P., Turco, R.F. and Hoagland, L.A. (2015) Sustaining Soil Quality in Intensively Managed High Tunnel Vegetable Production Systems: A Role for Green Manures and Chicken Litter. Hortscience, 50, 461-468.

[48] Knewtson, S.J.B., Kirkham, M.B., Janke, R.R., Murray, L.W. and Carey, E.E. (2012) Soil Quality after Eight Years under High Tunnels. Hortscience, 47, 1630-1633.

[49] Altamimi, M.E. (2016) Evaluating Organic and Conventional Management and Nitrogen Rate for Effects on Yield, Soil and Plant Nutrient of Tomato and Pac Choi Grown under High Tunnel and in the Field. Ph.D. Thesis, Kansas State University, Manhattan.

[50] Reeve, J. and Drost, D. (2012) Yields and Soil Quality under Transitional Organic High Tunnel Tomatoes. Hortscience, 47, 38-44.

[51] Bonanomi, G., D’ascoli, R., Antignani, V., Capodilupo, M., Cozzolino, L., Marazaioli, R., Pupolo, G., Rutigliano, F.A., Scelza, R., Scotti, R., Rao, M.A. and Zoina, A. (2011) Assessing Soil Quality under Intensive Cultivation and Tree Orchards in Southern Italy. Applied Soil Ecology, 47, 187-194. https://doi.org/10.1016/j.apsoil.2010.12.007

[52] Both, A., Reiss, E.J., Sudal, J., Holmstrom, K., Wyenandt, C., Kline, W. and Garrison, S. (2007) Evaluation of a Manual Energy Curtain for Tomato Production in High Tunnels. Horttechnology, 17, 467-472.

[53] Rader, H.B. and Karlsson, M.G. (2006) Northern Field Production of Leaf and Romaine Lettuce Using a High Tunnel. Horttechnology, 16, 649-654.

[54] Marshall, K.S., Erich, S., Hutton, M., Hutchinson, M. and Mallory, E. (2016) Nitrogen Availability from Compost in High Tunnel Tomato Production. Compost Science and Utilization, 24, 147-158. https://doi.org/10.1080/1065657X.2015.1102663

[55] Lamont, W.J. (1999) Vegetable Production Using Plasticulture. Extension Bulletin. Asian and Pacific Council, Food \& Fertilizer Technology Center, Saint Paul.

[56] O'connell, S., Rivard, C., Peet, M.M., Harlow, C. and Louws, F. (2012) High Tunnel and Field Production of Organic Heirloom Tomatoes: Yield, Fruit Quality, Disease, and Microclimate. Hortscience, 47, 1283-1290.

[57] Powell, M., Gunderson, B., Cowan, J., Miles, C.A. and Inglis, D.A. (2014) The Effect of Open-Ended High Tunnels in Western Washington on Late Blight and Physiological Leaf Roll among Five Tomato Cultivars. Plant Disease, 98, 1639-1647. https://doi.org/10.1094/PDIS-12-13-1261-RE

[58] Warren, N.D., Sideman, R.G. and Smith, R.G. (2015) Performance of High Tunnel Tomato Cultivars in Northern New England. Horttechnology, 25, 139-146.

[59] Zhao, Y., Gu, M.M., Bi, G.H., Evans, B. and Harkess, R. (2014) Planting Date Effect on Yield of Tomato, Eggplant, Pepper, Zinnia, and Snapdragon in High Tunnel in Mississippi. Journal of Crop Improvement, 28, 27-37. https://doi.org/10.1080/15427528.2013.858283 
[60] Rogers, M.A. and Wszelaki, A.L. (2012) Influence of High Tunnel Production and Planting Date on Yield, Growth, and Early Blight Development on Organically Grown Heirloom and Hybrid Tomato. Horttechnology, 22, 452-462.

[61] Villiers, D.S.D., Wien, H.C., Reid, J.E. and Albright, L.D. (2011) Energy Use and Yields in Tomato Production: Field, High Tunnel and Greenhouse Compared for the Northern Tier of the USA (Upstate New York). Acta Horticulturae, 893, 373380. https://doi.org/10.17660/ActaHortic.2011.893.34

[62] Martin, C.A. and Sideman, R.G. (2012) Survival and Yields of Fall-Planted Winter Sprouting Broccoli Grown in High Tunnels for Spring Harvest in the Northeastern United States. Horttechnology, 22, 345-352

[63] Borrelli, K., Koenig, R.T., Jaeckel, B.M. and Miles C.A. (2013) Yield of Leafy Greens in High Tunnel Winter Production in the Northwest United States. Hortscience, 48, 183-188.

[64] Zhao, X. and Carey, E.E. (2009) Summer Production of Lettuce, and Microclimate in High Tunnel and Open Field Plots in Kansas. Horttechnology, 19, 113-119.

[65] Wallace, R.W., Wsszelaki, A.L., Miles, C.A., Cowan, J.S., Martin, J., Roozen, J., Gundersen, B. and Inglis, D.A. (2012) Lettuce Yield and Quality When Grown in High Tunnel and Open-Field Production Systems under Three Diverse Climates. Horttechnology, 22, 659-668.

[66] Rowley, D., Black, B. and Drost, D. (2010) High Tunnel Strawberry Production. Utah State University Cooperative Extension, Logan.

https://extension.usu.edu/Files/Publications/Publication/Horticulture Hightunnels 2010-01pr.Pdf

[67] Jett, L.W. (2009) Growing Short Day Strawberries within High Tunnels. West Virginia University Extension, Morgantown. http://anr.ext.wvu.edu/R/Download/52995

[68] Medina, Y., Gosselin, A., Desjardins, Y., Gauthier, L., Harnois, R. and Khanizadeh, S. (2011) Effect of Plastic Mulches on Yield and Fruit Quality of Strawberry Plants Grown under High Tunnels. Acta Hort, 893, 1327-1332 https://doi.org/10.17660/ActaHortic.2011.893.156

[69] Riza, M.T., Soria, C., Medina-Minguez, J.J. and Martinez-Ferri, E. (2012) Incidence of Misshapen Fruits in Strawberry Plants Grown under Tunnels Is Affected by Cultivar, Planting Date, Pollination and Low Temperatures. Hortscience, 47, 15691573.

[70] Gaskell, M., Cantliffe, D.J., Stoffella, P.J. and Shaw, N.L. (2004) Field Tunnels Permit Extended Season Harvest of Small Fruits in California. Acta Hort, 659, 425-430. https://doi.org/10.17660/ActaHortic.2004.659.56

[71] Dorais, M., Gaudreau, L., Bordeleau, M., Gosselin, A., Medina, Y., Gauthier, L., Desjardins, Y. and Khanizadeh, S. (2012) High Tunnel Production of Organic Raspberries. Proceedings of the Canadian Organic Science Conference and Science Cluster Strategic Meetings, Winnipeg, 21-23 February 2012, 125.

[72] Spalholz, H., Kelly, M.J. and Pritts, M. (2006) Using High Tunnels to Extend the Raspberry Season into Late Fall. Hortscience, 40, 493.

[73] Demchak, K. (2009) Small Fruit Production in High Tunnels. Horttechnology, 19, 44-49.

[74] Hanson, E., Von Weihe, M., Schilder, A.C., Chanon, A.M. and Scheerens, J.C. (2011) High Tunnel and Open Field Production of Floricane- and PrimocaneFruiting Raspberry Cultivars. Horttechnology, 21, 412-418.

[75] Rom, C.R., Friedrich, H., Mcafee, J., Garcia, M.E., Johnson, D., Popp, J., Vincent, C. 
and Van Iersel, M. (2008b) Potential for High Tunnel Organic Berry Production for Extended and Alternative Season. Hort Science, 43, 610.

[76] Johnson, S.N., Young, M.W. and Karley, A.J. (2012) Protected Raspberry Production Alters Aphid-Plant Interactions but Not Aphid Population Size. Agricultural and Forest Entomology, 14, 217-224. https://doi.org/10.1111/j.1461-9563.2011.00561.x

[77] Thompson, E., Strik, B.C., Finn, C.E., Zhao, Y. and Clark, J.R. (2009) High Tunnel versus Open Field: Management of Primocane-Fruiting Blackberry Using Pruning and Tipping to Increase Yield and Extend the Fruiting Season. Hortscience, 44, 1581-1587.

[78] Hanson, E. (2012) Primocane-Fruiting Blackberry Performance in High Tunnels in Cold Regions. Acta Hort, 946, 397-401 https://doi.org/10.17660/ActaHortic.2012.946.66

[79] Rom, C.R., Friedrich, H., Mcafee, J., Garcia, M.E., Johnson, D. and Popp, J. (2008a) Early Performance of Organic Managed Floricane and Primocane Blackberries and Raspberries Grown in High Tunnels for Extended Season. Hort Science, 43, 1228.

[80] Ogden, A.B. and Van Iersel, M.W. (2009) Southern Highbush Blueberry Production in High Tunnels: Temperatures, Development, Yield, and Fruit Quality during the Establishment Years. Hortscience, 44, 1850-1856.

[81] Lang, G.A. (2009) High Tunnel Tree Fruit Production: The Final Frontier? Horttechnology, 19, 50-55.

[82] Lang, G.A. (2013) Tree Fruit Production in High Tunnels: Current Status and Case Study of Sweet Cherries. Acta Horticulturae, 987, 73-81. https://doi.org/10.17660/ActaHortic.2013.987.10

[83] Fruit Growers News (2008) English Growers Love Their High Tunnels. http://fruitgrowersnews.com/Article/English-Growers-Love-Their-High-Tunnels/

[84] Heidenreich, C., Pritts, M., Demchak, K., Hanson, E., Weber, C. and Kelly, M.J. (2012) High Tunnel Raspberries and Blackberries. Cornell University, New York.

[85] Galinato, S.P. and Miles, C.A. (2013) Economic Profitability of Growing Lettuce and Tomato in Western Washington under High Tunnel and Open-Field Production Systems. Horttechnology, 23, 453-461.

[86] Sydorovych, O., Rivard, C.L., O'connell, S., Harlow, C.D., Peet, M.M. and Louws, F.J. (2013) Growing Organic Heirloom Tomatoes in the Field and High Tunnels in North Carolina: Comparative Economic Analysis. Horttechnology, 23, 227-236.

[87] Vescera, M. and Brown, R.N. (2016) Effects of Three Production Systems on Muskmelon Yield and Quality in New England. Hortscience, 51, 510-517.

[88] Conner, D.S., Waldman, K.B., Montri, A.D., Hamm, M.W. and Biernbaum. J.A. (2010) Hoophouse Contributions to Economic Viability: Nine Michigan Case Studies. Horttechnology, 20, 877-884.

[89] Rodriguez, H.G., Popp, J., Thomsen, M., Friedrich, H. and Rom, C.R. (2012) Economic Analysis of Investing in Open-Field or High Tunnel Primocane-Fruiting Black-Berry Production in Northwestern Arkansas. Horttechnology, 22, 245-251.

[90] Pottorff, L.P. and Panter, K.L. (2009) Integrated Pest Management and Biological Control in High Tunnel Production. Horttechnology, 19, 61-65.

[91] Scotti, R., Bonanomi, G., Scclza, R., Zoina, A. and Rao, M.A. (2015) Organic Amendments as Sustainable Tool to Recovery Fertility in Intensive Agricultural Systems. Journal of Soil Science and Plant Nutrition, 15, 333-352. https://doi.org/10.4067/s0718-95162015005000031 
[92] Tremlett, G. (2005) Spain's Greenhouse Effect: The Shimmering Sea of Polythene Consuming the Land.

https://www.theguardian.com/world/2005/sep/21/spain.gilestremlett

[93] Ali, M.A. and Ahmad, C.S. (2008) Role of Government Sector in the Development of Protected Horticulture in Pakistan. In: Abbasi, N.A. and Habib, U., Eds., Protected Horticulture, Department of Horticulture, University of Rawalpindi, Rawalpindi, 1-124.

[94] In Paper Magazine (2012) Tunnel Farming Losing Momentum. https://www.dawn.com/news/771932

[95] Byczynski, L. (2008) The Flower Farmer: An Organic Grower's Guide to Raising and Selling Cut Flowers. 2nd Edition, Chelsea Green Publishing, Chelsea, 284.

[96] Wien, H.C. (2008) Floral Crop Production in High Tunnels. Horttechnology, 19, 56-60.

Submit or recommend next manuscript to SCIRP and we will provide best service for you:

Accepting pre-submission inquiries through Email, Facebook, LinkedIn, Twitter, etc. A wide selection of journals (inclusive of 9 subjects, more than 200 journals)

Providing 24-hour high-quality service

User-friendly online submission system

Fair and swift peer-review system

Efficient typesetting and proofreading procedure

Display of the result of downloads and visits, as well as the number of cited articles

Maximum dissemination of your research work

Submit your manuscript at: http://papersubmission.scirp.org/

Or contact as@scirp.org 